\title{
IONIC MODELING OF LITHIUM MANGANESE SPINEL MATERIALS \\ FOR USE IN RECHARGEABLE BATTERIES
}

\author{
CONF-950412--65 \\ RANDALL T. CYGAN*, HENRY R. WESTRICH* ${ }^{*}$ AND DANIEL H. DOUGHTY** \\ *Sandia National Laboratories, Geochemistry Department, Albuquerque, NM 87185-0750 \\ ** Sandia National Laboratories, Exploratory Batteries Department, Albuquerque, NM 87185- \\ 0614
}

\begin{abstract}
In order to understand and evaluate materials for use in lithium ion rechargeable battery electrodes, we have modeled the crystal structures of various manganese oxide and lithium

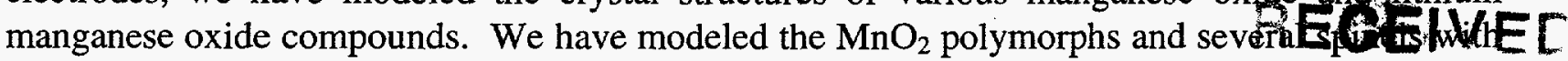
intermediate compositions based on the amount of lithium inserted into the tetphodral site. Three-dimensional representations of the structures provide a basis for identifying site occupancies, coordinations, manganese valence, order-disorder, and potentially new opptofor enhanced cathode behavior. X-ray diffraction simulations of the crystal structures provide good agreement with observed patterns for synthesized samples. Ionic modeling of these materials consists of an energy minimization approach using Coulombic, repulsive, and van der Waals interactions. Modeling using electronic polarizabilities (shell model) allows a systematic analysis of changes in lattice energy, cell volume, and the relative stability of doped structures using ions such as aluminum, titanium, nickel, and cobalt.
\end{abstract}

\section{INTRODUCTION}

An alternative approach to the usual method of synthesizing and testing new oxide materials is to develop atomistic computer models that relate intrinsic properties to battery performance, which is the basis of a predictive model. For example, lattice expansion and contraction upon lithiation and delithiation, respectively, causes the buildup of stress in $\mathrm{LiMn}_{2} \mathrm{O}_{4}$ crystals, accompanied by swelling and contraction of the cathode. These physical changes have been implicated in poor capacity retention on cycling of rechargeable batteries ${ }^{1}$. Developing a model that predicts lattice expansion on lithiation and, more importantly, identifies dopants that minimize lattice expansion while retaining capacity could lead us to cathode compositions with improved performance.

Our approach involves the evaluation of the forces and energies associated with the component ions of materials by the use of ionic models. This atomistic approach can predict the relative stability of selected phases and their doped derivatives, and provide energy-optimized crystal structures and physical and electrical properties. We have chosen this modeling method to examine the lithium manganese oxides that have received significant attention in their use as cathodes for rechargeable batteries. We hope to provide insights into the choice of appropriate dopants and dopant levels that may lead to the improved performance of these cathodes in lithium ion rechargeable batteries.

A variety of compounds and structures make up the Li-Mn-O ternary system. One of the best phases for a cathode material is the $\mathrm{LiMn}_{2} \mathrm{O}_{4}$ spinel that exhibits a voltage plateau of $4 \mathrm{~V}^{2}$. The crystal structure of $\mathrm{LiMn}_{2} \mathrm{O}_{4}$ is characterized by a cubic (isometric) unit cell (space group Fd3m)

\section{DISTRIBUTION OF THIS DOCUMENT IS UNLIMITED}




\section{DISCLAIMER}

This report was prepared as an account of work sponsored by an agency of the United States Government. Neither the United States Government nor any agency thereof, nor any of their employees, makes any warranty, express or implied, or assumes any legal liability or responsibility for the accuracy, completeness, or usefulness of any information, apparatus, product, or process disclosed, or represents that its use would not infringe privately owned rights. Reference herein to any specific commercial product, process, or service by trade name, trademark, manufacturer, or otherwise does not necessarily constitute or imply its endorsement, recommendation, or favoring by the United States Government or any agency thereof. The views and opinions of authors expressed herein do not necessarily state or reflect those of the United States Government or any agency thereof. 


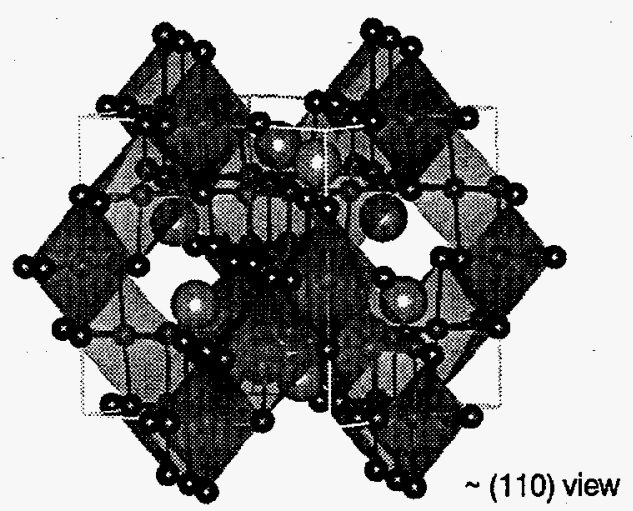

Figure 1. Crystal structure of $\mathrm{LiMn}_{2} \mathrm{O}_{4}$ showing manganese octahedra and lithium ions.

comprised of 8 lithium ions, 16 manganese ions (equal distribution of 3+ and 4+ valence states), and 32 oxygens giving eight $\mathrm{LiMn}_{2} \mathrm{O}_{4}$ units per unit cell. $\mathrm{LiMn}_{2} \mathrm{O}_{4}$ is a normal spinel with the low charge lithium ion in the tetrahedral site and the higher charge manganese ions located in the octahedral sites (Figure 1). The dense structure of this material (density of $4.281 \mathrm{~g} / \mathrm{cm}^{3}$ ) is related to the edge sharing of the manganese octahedra. The ability to recharge cathodes comprised of $\mathrm{LiMn}_{2} \mathrm{O}_{4}$ is directly related to the open channels along [110] direction where the monovalent lithiums are relatively easy to diffuse (see Figure 1). The completely oxidized $\mathrm{LiMn}_{2} \mathrm{O}_{4}$ material is the $\lambda-\mathrm{MnO}_{2}$ phase having the same structure as $\mathrm{LiMn}_{2} \mathrm{O}_{4}$ but without the lithium ions $\left(\square_{1.0} \mathrm{Mn}_{2} \mathrm{O}_{4}\right)$; the manganese is completely in the $4+$ valence state. There are two additional polymorphs of $\mathrm{MnO}_{2}$, tetragonal pyrolusite $\left(\beta-\mathrm{MnO}_{2}\right)$ and orthorhombic $\left(\gamma-\mathrm{MnO}_{2}\right)$. The ionic modeling of these phases and the $\mathrm{Al}^{3+}-, \mathrm{Ti}^{4+}-, \mathrm{Ni}^{2+}$-, and $\mathrm{Co}^{2+}$-doped $\mathrm{LiMn}_{2} \mathrm{O}_{4}$ phases, which have been previously synthesized and tested ${ }^{1-3}$, is presented below.

\section{THEORETICAL APPROACH}

An ionic approximation is used to model the interactions among the components of the $\mathrm{LiMn}_{2} \mathrm{O}_{4}$ phase and the doped derivatives. Energy-minimized structures are obtained based on the summation of all possible pair-wise ionic interactions allowing the entire assembly of ions to rearrange within the confines of the unit cell. The interaction energy $\Phi$ of two ions is based on the summation of Coulombic, repulsive, and van der Waals energies as a function of the distance $r$ between the ions ${ }^{4}$ :

$$
\Phi\left(r_{i j}\right)=\frac{z_{i} z_{j} e^{2}}{r_{i j}}+A_{i j} \exp \left(-r_{i j} / \rho_{i j}\right)-\frac{C_{i j}}{r_{i j}^{6}}
$$

The Coulombic or electrostatic term includes the electron charge e and the ionic charge $z$. The interaction parameters $\mathrm{A}, \rho$, and $\mathrm{C}$ are derived from the observed structures, elastic constants, and dielectric properties of simple binary oxides, as well as from spectroscopic measurements and molecular orbital calculations. The latter two energy terms in equation (1), representing the short range interactions, are often referred to collectively as a Buckingham potential. Table I provides the interaction parameters used in the present study. The $\mathrm{Mn}^{4+}-\mathrm{O}^{2-}$ parameters were not available in the literature and were derived by best fit of the model to the observed structures of pyrolusite, ramsdellite, and $\lambda-\mathrm{MnO}_{2}$. The total energy of the crystal at $0 \mathrm{~K}$, or lattice energy, is obtained by the summation of the interactions of the $i$ ions of a reference cell (usually the unit 
Table I. Buckingham potentials and spring constants for component ions; shell (sh) and core (co) values are provided when applicable.

\begin{tabular}{|c|c|c|c|c|}
\hline Interaction Pair & $\mathrm{A}(\mathrm{eV})$ & $\rho(\AA)$ & $C\left(\mathrm{eV} \AA^{6}\right)$ & Ref. \\
\hline $\mathrm{Li}^{+} \mathrm{sh}-\mathrm{O}^{2-} \mathrm{sh}$ & 292.3 & 0.3472 & 0.00 & 4 \\
\hline $\mathrm{Li}^{+} \mathrm{sh} \cdot \mathrm{Li}^{+} \mathrm{sh}$ & 1153.8 & 0.1364 & 0.00 & 4 \\
\hline $\mathrm{Mn}^{4+}-\mathrm{O}^{2-} \mathrm{sh}$ & 1975.0 & 0.2900 & 0.00 & this study \\
\hline $\mathrm{Mn}^{3+}-\mathrm{O}^{2-} \mathrm{sh}$ & 1257.9 & 0.3214 & 0.00 & 4 \\
\hline $\mathrm{Al}^{3+}-\mathrm{O}^{2-} \mathrm{sh}$ & 1460.3 & 0.2991 & 0.00 & 5 \\
\hline $\mathrm{Ti}^{4+} \operatorname{sh}-\mathrm{O}^{2-} \mathrm{sh}$ & 754.2 & 0.3879 & 0.00 & 4 \\
\hline $\mathrm{Ni}^{2+} \mathrm{sh}-\mathrm{O}^{2-} \mathrm{sh}$ & 683.5 & 0.3332 & 0.00 & 4 \\
\hline $\mathrm{Co}^{2+} \mathrm{sh}-\mathrm{O}^{2-} \mathrm{sh}$ & 696.3 & 0.3362 & 0.00 & 4 \\
\hline $\mathrm{O}^{2-} \mathrm{sh}-\mathrm{O}^{2-} \mathrm{sh}$ & 22764.0 & 0.1490 & 27.88 & 5 \\
\hline \multicolumn{5}{|c|}{$\mathrm{k}\left(\mathrm{eV} / \AA^{2}\right)$} \\
\hline $\mathrm{Li}^{+} \mathrm{sh}-\mathrm{Li}^{+} \mathrm{co}$ & 7.99 & & & 4 \\
\hline $\mathrm{Ti}^{4+} \mathrm{sh}-\mathrm{Ti}^{4+} \mathrm{co}$ & 37.3 & & & 4 \\
\hline $\mathrm{Ni}^{2+} \mathrm{sh}-\mathrm{Ni}^{2+} \mathrm{co}$ & 8.77 & & & 4 \\
\hline $\mathrm{Co}^{2+} \mathrm{sh}-\mathrm{Co}^{2+} \mathrm{co}$ & 10.74 & & & 4 \\
\hline $\mathrm{O}^{2-} \mathrm{sh}-\mathrm{O}^{2-} \mathrm{co}$ & 19.73 & & & 4 \\
\hline
\end{tabular}

cell) with each other and all ions in the other cells:

$$
E_{\text {total }}=\frac{1}{2} \sum_{i}^{\text {one cell }} \sum_{j \neq i}^{\text {all cells }} \Phi\left(r_{i j}\right)
$$

The factor of one-half is required so that interactions are only summed once. Due to the long range nature of the Coulombic $1 / \mathrm{r}$ term, the summations are carried out partially in reciprocal space in order to achieve proper energy convergence. Typically, ionic models assume a rigid ion approximation by representing the ion as a point or hard sphere of charge. Because of the high electronic polarizability associated with the oxygen anion, and to a lesser extent $\mathrm{Li}^{+}, \mathrm{Ti}^{4+}, \mathrm{Ni}^{2+}$, and $\mathrm{Co}^{2+}$, it is necessary to use a more sophisticated shell model for simulating the lithium manganese oxides. Thereby, the electron cloud (shell) is allowed to be shifted away from the atomic nucleus (core) and leads to electron sharing between ions. A simple harmonic potential characterized by a spring constant $\mathrm{k}$ is used to represent this additional interaction:

$$
\mathrm{E}_{\text {polar }}=\frac{1}{2} \mathrm{kx}^{2}
$$

The separation distance between the core and shell is denoted by $\mathrm{x}$. The core and shell of an ion can have partial charges but the net sum must be equivalent to the formal charge for that ion. We use a core charge of 0.29 and 0.71 respectively for the $\mathrm{Li}^{+}$core and shell and 0.00 and -2.00 respectively for the $\mathrm{O}^{2-}$ core and shell. For the simulations involving the dopants $\mathrm{Ti}^{4+}, \mathrm{Ni}^{2+}$, and $\mathrm{Co}^{2+}$ ions we maintain the entire formal charge on the shell component. $\mathrm{Mn}^{4+}, \mathrm{Mn}^{3+}$, and $\mathrm{Al}^{3+}$ are represented as simple rigid ions with full formal charge.

Calculations were performed using the lattice energy program GULP (General Utility Lattice Program) written by Julian Gale of Imperial College of London. Initial structures of the $\mathrm{LiMn}_{2} \mathrm{O}_{4}$ and doped derivatives were based on the observed structure parameters and asymmetric unit of $\mathrm{LiMn}_{2} \mathrm{O}_{4}{ }^{6}$. A unit cell was generated and then converted to $\mathrm{P} 1$ symmetry, thereby allowing all unit cell components to freely translate during the energy minimization. The unit cell was allowed to expand or contract accordingly to simulate constant pressure conditions, however, the cell was constrained to an isometric crystal system. Direct substitution of $\mathrm{Al}^{3+}$ and 


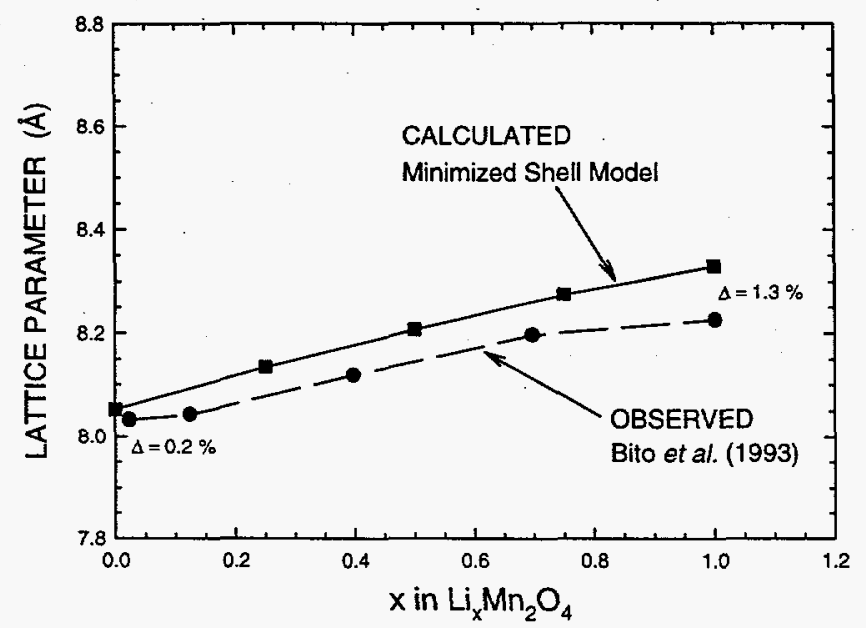

Figure 2. Calculated lattice parameter for energy-minimized structures of $\mathrm{Li}_{\mathrm{x}} \mathrm{Mn}_{2} \mathrm{O}_{4}$ with varying amounts of $\mathrm{Li}^{+}$. The relative difference between theory and observation are provided for the endmember compositions.

$\mathrm{Ti}^{4+}$ for, respectively, $\mathrm{Mn}^{3+}$ and $\mathrm{Mn}^{4+}$ in the $\mathrm{LiMn}_{2} \mathrm{O}_{4}$ lattice provided initial doped structures. $\mathrm{Co}^{2+}$ and $\mathrm{Ni}^{2+}$ doping required conversion of some $\mathrm{Mn}^{3+}$ to $\mathrm{Mn}^{4+}$ in order to preserve charge neutrality in the unit cell.

\section{RESULTS AND DISCUSSION}

Initial energy minimization calculations examined the behavior of the $\mathrm{LiMn}_{2} \mathrm{O}_{4}$ lattice with various $\mathrm{Li}^{+}$amounts that would be expected during the charge/discharge process of the battery operation. Figure 2 shows the variation in the calculated lattice parameter for selected compositions along the $\lambda-\mathrm{MnO}_{2}-\mathrm{LiMn}_{2} \mathrm{O}_{4}$ join. The simulations indicate a contraction of the lattice with removal of the lithium ions and are in very good agreement with some recent experimentally determined values ${ }^{1}$. The relative stabilities of the doped $\mathrm{LiMn}_{2} \mathrm{O}_{4}$ materials are

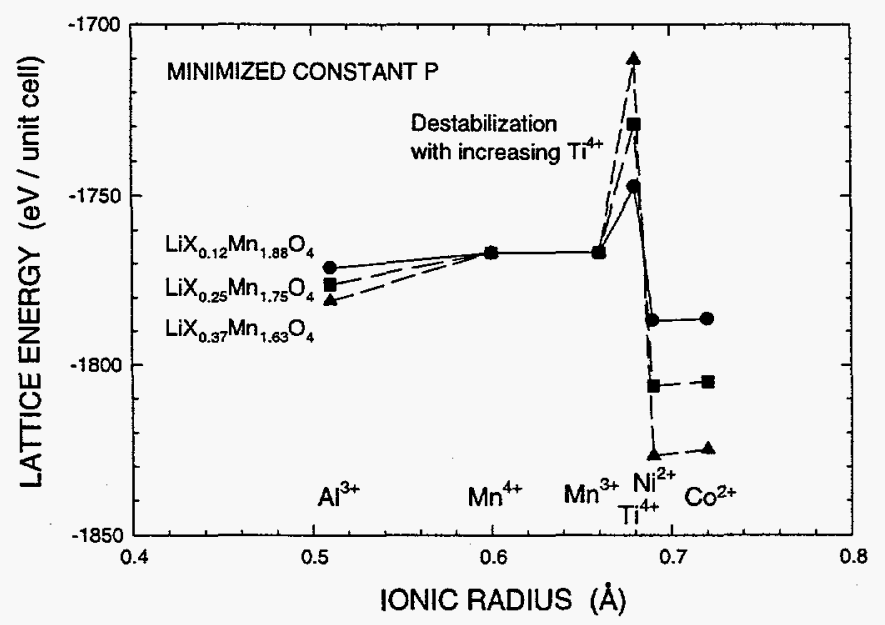

Figure 3. Change in lattice energy as a function of ionic radii for doped $\mathrm{LiMn}_{2} \mathrm{O}_{4}$ compounds relative to the undoped material $\left(\mathrm{Mn}^{4+}-\mathrm{Mn}^{3+}\right.$ segment $)$. 


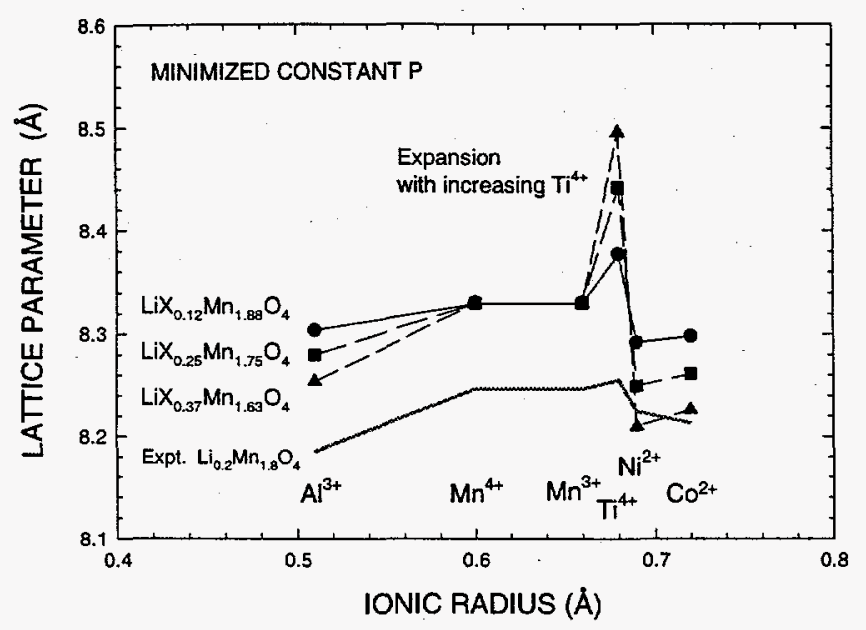

Figure 4. Change in calculated lattice parameter as a function of ionic radii for doped $\mathrm{LiMn}_{2} \mathrm{O}_{4}$ compounds relative to the undoped material $\left(\mathrm{Mn}^{4+}-\mathrm{Mn}^{3+}\right.$ segment). The trend of these results are in agreement with the experimental observations ${ }^{1}$.

presented in Figure 3 where the trends in the calculated lattice energy are exhibited as a function of the ionic radii for various dopant levels $\left(\mathrm{LiX}_{\mathrm{x}} \mathrm{Mn}_{2-\mathrm{x}} \mathrm{O}_{4}\right.$ where $\mathrm{x}$ is $0.12,0.25$, and 0.37 , corresponding to 1,2 , and 3 dopant atoms per unit cell). The $\mathrm{Al}^{3+}, \mathrm{Ni}^{2+}$, and $\mathrm{Co}^{2+}$ results all exhibit a stabilization of the $\mathrm{LiMn}_{2} \mathrm{O}_{4}$ lattice with increasing dopant. Conversely, the $\mathrm{Ti}^{4+}$ calculations suggest a strong destabilization for all dopant levels relative to the undoped $\mathrm{LiMn}_{2} \mathrm{O}_{4}$ (represented by the $\mathrm{Mn}^{4+}-\mathrm{Mn}^{3+}$ segment at $-1767 \mathrm{eV} /$ unit cell). The calculated lattice parameters for the doped materials are presented in a similar fashion in Figure 4. A contraction of the $\mathrm{LiMn}_{2} \mathrm{O}_{4}$ lattice is observed with increasing amount of $\mathrm{Al}^{3+}, \mathrm{Ni}^{2+}$, and $\mathrm{Co}^{2+}$, whereas the $\mathrm{Ti}^{4+}$ induces a lattice expansion. These trends in the simulation results are in agreement with experimental values ${ }^{1}$.

The energy-minimized structures of these doped materials are useful for comparison with the cathode materials synthesized in our laboratory ${ }^{3}$. X-ray diffraction patterns can be simulated to interpret the shifting in peak position at various dopant levels. This is most helpful at the high diffraction angles where the slight changes in d-spacings are resolvable (Figure 5). This approach has been used in the synthesis of $\mathrm{LiMn}_{2} \mathrm{O}_{4}$ doped with $\mathrm{Al}^{3+}, \mathrm{Ni}^{2+}$, and $\mathrm{Co}^{2+}$. It was

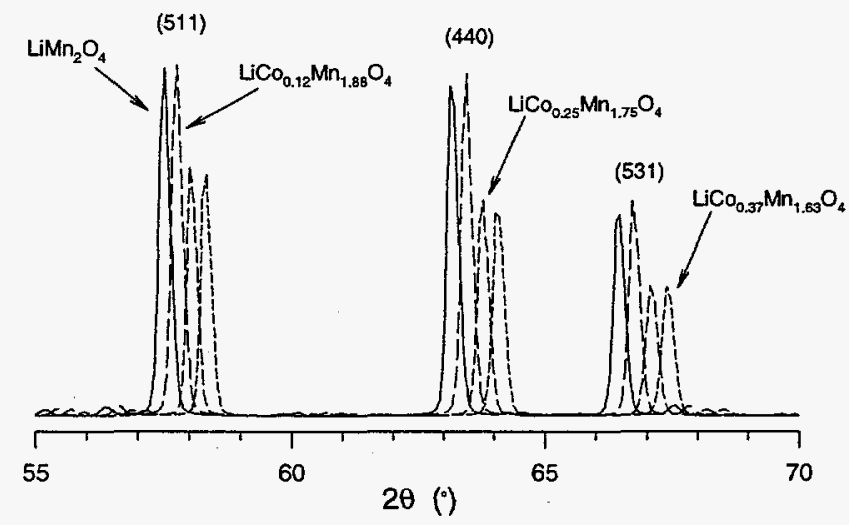

Figure 5. Simulated X-ray diffraction patterns for undoped and $\mathrm{Co}^{2+}$-doped $\mathrm{LiMn}_{2} \mathrm{O}_{4}$ showing decrease in $\mathrm{d}$-spacing with increasing $\mathrm{Co}^{2+}$ content. 
observed that the $\mathrm{Al}^{3+}$-doped material $(\mathrm{x}=0.12)$ provided the best battery capacity among those tested $^{3}$.

The ionic model simulations of the lithium manganese oxides and their doped derivatives provide a fundamental basis for evaluating the crystal chemical and structural controls on lithium battery performance. By a systematic evaluation of lattice energies, lattice parameters, and their relative values, in particular, as a function of lithium content, we may be able to evaluate the critical input for guiding the synthesis and testing of optimal cathode materials. In particular, future modeling will address the significance of other dopants and their effect on the expansion and contraction of the $\mathrm{LiMn}_{2} \mathrm{O}_{4}$ lattice, especially as a function of lithium content for evaluating the capacity retention on cycling.

\section{CONCLUSIONS}

The ionic modeling of lithium manganese spinels and their doped derivatives provides a fundamental basis for evaluating the interaction of component ions and predicting their relative stabilities and structural properties. A decrease is observed in the calculated lattice parameter for $\mathrm{Li}_{\mathrm{x}} \mathrm{Mn}_{2} \mathrm{O}_{4}$ as a function of decreasing $\mathrm{Li}^{+}$content, in agreement with experimental values. There is a stabilization and contraction of the $\mathrm{LiMn}_{2} \mathrm{O}_{4}$ lattice with increased amounts of $\mathrm{Al}^{3+}, \mathrm{Ni}^{2+}$, and $\mathrm{Co}^{2+}$, whereas the calculations for the $\mathrm{Ti}^{4+}$-doped materials indicate the converse behavior. Furthermore, the ionic modeling provides a basis for screening potential dopants and new materials that would be both time-consuming and costly to synthesize and test in the laboratory.

\section{ACKNOWLEDGMENTS}

The authors are appreciative of Tim Boyle, Bryan Johnson, Sam Levy, and Jim Voigt for their helpful discussions and comments on the material synthesis and battery testing. Behnam Vessal is gratefully acknowledged for his help in selecting appropriate Buckingham potentials and in the use of the GULP code. This work was supported by the U.S. Department of Energy, Office of Basic Energy Sciences, Chemical Sciences Program under contract DE-AC04-94AL85000.

\section{REFERENCES}

1. Y. Bito, H. Murai, S. Ito, M. Hasegawa, Y. Toyoguchi, E.C.S. Proc. PV93-23, 461 (1993).

2. J.M. Tarascon, E. Wang, F.K. Shokoohi, W.R. McKinnon, and S. Colson, J. Electrochem. Soc. 138, 2859 (1991).

3. T.J. Boyle, D.H. Doughty, B.A. Hernandez, B.C. Johnson, E.M. Knecht, S.C. Levy, C.J. Tafoya, and J.A. Voigt, this volume (1995).

4. G.V. Lewis and C.R.A. Catlow, J. Phys. Chem. 18, 1149 (1985).

5. R.A. Jackson and C.R.A. Catlow, Molec. Simul. 1, 207 (1988).

6. A. Mosbah, A. Verbaere, and M. Tournoux, Mater. Res. Bull. 18, 1375 (1983). 